\title{
Assessments of Citizen Willingness to Support Urban Forestry: An Empirical Study in Alabama
}

\author{
Yaoqi Zhang and Bin Zheng
}

\begin{abstract}
Using a survey conducted in Alabama, U.S., this study investigates the attitudes of urban residents toward urban trees and how they would like to support urban tree programs. An ordered logistic model and ordinary least square regression were applied in the analyses. It is found, in general, that people prefer to have trees on their property and in their community for all gender, age, race, income, and other family background, but individuals with higher education had a tendency to like more trees. The most desirable amenity of trees is the improved appearance. The potential risks and hazards would discourage them from having trees in their communities. It is found that each person's voluntary willingness to donate is significantly less than the amount that he or she feels everyone should contribute to support the programs (e.g., taxation). The awareness of the presence of a tree agency and service can significantly increase the amount of donation a person is willing to make. While private donation is widely agreed upon as an important source of support, using alcohol and tobacco taxes as funding for financing urban tree programs receives more support than the idea of using corporate income tax and property tax. The results indicate that the citizen willingness to support urban forestry are affected by various factors, therefore, a holistic approach is needed to promote city tree programs. Key Words. Green Infrastructure; Ordered Logistic Model; Public Participation; Taxation; Willingness to Pay.
\end{abstract}

Amenities have been driving urban growth and becoming magnets of the cities (Clark et al. 2002). For example, a lot of beautiful cities are chosen as technological innovation centers as they are more capable of attracting more talented people nationally and internationally. In any specific city, the U.S.'s growing population is increasingly spreading into the countryside and the rural-urban interface in search of green areas and associated amenities. Trees and greenspace play a special role in enhancing the livability of communities. Urban and community trees, an important part of a city's green infrastructure, provide valuable services just like other forms of municipal infrastructure. The services provided by trees and greenspace to communities include energy savings, improved air quality, aesthetics, health benefits, habitats for birds and other wildlife, and recreation opportunities. These values are reflected in higher real estate prices, lower electric bills, and an influx of tourists, as well as talented people and businesses (Clark et al. 2002; Dwyer et al. 1992; Orland et al. 1992; Bradley 1995; Jim and Chen 2006; Deng et al. 2010; Zheng et al. 2011).

Community involvement is critical for the continued vitality of urban forests (Dwyer et al. 2002). The number of local urban and community tree programs and related activities has increased in recent years. Hauer and Johnson (2008) found a significant increase in local urban forestry activity, which had increased on average by $2.1 \%$ annually from 1997 to 2002, through reported Performance Measures and Accountability System (PMAS) data to the federal Urban \& Community forestry program. There are more than 3,400 communities that are currently a Tree City USA. The number of Alabama, U.S.'s towns and cities that are certified in Tree City USA has grown from one in 1979 to more than eighty in the 2000s.

Financial assistance has been suggested as the most effective means to promote urban forestry programs (Wray and Prestemon
1983; Studer 2003; Straka et al. 2005). Different kinds of activities in urban and community forestry programs are provided through various funding. The most important activities include tree planting, public awareness, and volunteer training. Now, many other activities are also occasionally supported, for example, carbon dioxide emission reduction credits, and shade tree programs for energy conservation, stormwater management, and air pollution mitigation. Financial assistance provides money for activities to increase tree inventories and natural resources, develop management plans, and conduct workshops to train community members.

Individuals and business sectors are also an important source, providing an assured source of income for many nonprofit organizations once a solicitation program is in place. An organization supported by its community will also find it easier to secure funding source and corporate support. Corporate entities provide funding to signal this greenness (Majumdar and Zhang 2009). Traditionally, individuals make gifts of either money or time. Members are volunteers who provide the manpower necessary for membership drives, fundraising events, and lobbying. Volunteers can serve as a link between a nonprofit and a potential donor, especially a corporate donor. For example, Trees Atlanta, founded in 1985, has been a prime force in addressing Atlanta residents' loss, creating and increasing greenspace. Nearly 25 years after its inception, Trees Atlanta has inspired thousands of Atlanta citizens to advocate for better tree ordinances to protect the city's urban landscape. The activities have been largely supported by thousands of volunteers, as well as private donations (Tree Atlanta).

Although volunteers and individual and corporate donors provide much needed assistance, financial support for urban forestry is still short and often inconsistent (Center for Urban Forest Research 2003). Securing financial resources, as well as develop- 
ing diverse and adaptable long term fund-raising strategies and funding mechanisms is, thus, very important. Current information about the financial sources for community tree programs is lacking, partly due to the diverse sources (a mix of public funding; cost avoidance, reduction, and recovery; trust/private funds) and changing organizations involved (Zhang et al. 2009).

In order to facilitate the development of urban and community forestry programs from a financial perspective, and to formulate a workable strategy, the industry needs to explore, assemble, and share information regarding public attitudes toward urban trees and the public's willingness to support urban forestry programs financially. Public attitudes have a significant influence on many aspects, such as budgeting, public involvement and participation, integration of tree programs into social infrastructure, and community identity (see Sommer et al. 1994; Barro et al. 1997; Austin 2002). Therefore, it is important to consult the public and better understand their attitudes in developing a diverse and adaptable strategy. Obtaining information regarding public preferences to support urban tree programs is, as a result, important.

While many studies on urban forestry have analyzed public attitudes on the benefits of urban trees (e.g., Dwyer and Miller 1999; McPherson et al. 1999; Thompson et al. 1999; Tyrvainen 2001; Gorman 2004; Lohr et al. 2004), a more critical issue is in developing a sustainable and adequate community forestry support program (e.g., Lorenzo et al. 2000). The purpose of this paper is twofold. First, to examine public attitudes to urban trees including both amenities and negative impacts from trees, from the demand side. Secondly, to explore the public's willingness and preferences to financially support urban forestry programs from a supply side.

\section{DATA COLLECTION AND METHODOLOGY}

To know public attitudes toward urban trees and to formulate a financial strategy for urban forest programs acceptable to the public, a household survey was conducted with a mail-in questionnaire. Questions related to the following aspects were asked:

- Perceived importance of urban trees on personal and community property

- Perceived benefits and negative features of urban trees and forests

- Attitudes toward public funding of urban forests and the variety of sources of funding

- Participation in urban forestry activities

- Willingness to donate money or volunteer time to urban tree activities

- Socio-demographic information such as age, education, employment status, income, race, gender and number of children

The survey was conducted from late 2004 to early 2005. Survey Sampling International (One Post Road, Fairfield, CT, 06824 U.S.) was asked to obtain 3,500 random home addresses (including phone number, addresses, and names) from major cities in the state of Alabama (Greenville, Cullman, Mobile, Fairhope, Dothan, Montgomery, Demopolis, Auburn, Hoover, Birmingham, Huntsville, Florence).

The questionnaires were mailed to the 3,500 participants. Approximately 280 completed responses were received, with roughly 350 returned mailings (due to relocating homes or the database used by Survey Sampling International having been too old). After three to four weeks the questionnaires were mailed again to those who did not respond. Approximately 220 completed responses were received, with 50 additional bad addresses. After one month, the study authors randomly selected 250 addresses who never responded. These addresses were targeted with the enclosed incentive of 3.7 U.S. dollars (the value of postage). This method did work to some degree, since 80 of these 250 addresses were also received. In total, 582 responses were received, of which there were 102 incomplete responses. Overall there was a $20 \%$ response rate from 3,100 valid addresses. The response rate was a little lower than expected considering the nature of the survey.

In the data analysis, simple statistical methods are used to describe the attitudes and preferences to urban trees and financing strategies. OLS (ordinary linear regression) regression and ordered logistic model are further applied to investigate what factors might influence the preferences. For example, the amount of monetary value that the respondents consider "should" be donated (e.g., using tax to impose the changes to all households) and "would" be donated (voluntary contribution) as a function of family background, personal characteristics, and their attitude indicators was of particular interest. The difference between public choice (should donate) and individual choice (willingness to donate or would donate) has been investigated for several decades (e.g., Arrow 1951). People have one set of preferences that govern their private choices, and another set that governs social actions and choices (Kelman 1981; Sagoff 1988; Sen 1995). For example, individual choice of grazing under open access institutional arrangement would cause the tragedy of the commons due to free rider problem. However, open access would not be chosen if public choice arrangement is made.

The central question here-"should donate" versus "would donate"-is to see the individual behaviors under current institution of voluntary contribution versus public choice of forced payment on public support to urban tree program. For example, many people would say they would not donate, but they might support to collect additional property tax to support the urban forest program. For this purpose, a question in the questionnaires was intended to ask the amounts of an average family support urban tree program annually through state sales tax, local property tax, estate tax alcohol, tobacco tax, state income tax, corporate income tax, and private donations to know how much the respondents think is appropriate (or should) to support urban tree programs. The second question asked regarded the amount the respondent would like to donate of their money to support urban tree activities in their area annually.

Following research by others (e.g., Yen et al. 1997; SazSalazar and Garcia-Menendez 2001), it is hypothesized that an individual's response to support urban tree programs depends on his/her income, education, race, gender, experience, and residential location. The OLS regression models are as follows:

$$
\begin{aligned}
& \text { Should donate }=\beta_{0}+\beta_{\mathrm{i}} \chi_{\mathrm{i}}+\varepsilon \\
& \text { Would donate }=\beta_{0}+\beta_{\mathrm{i}} \chi_{\mathrm{i}}+\varepsilon
\end{aligned}
$$

where should donate is the response to the answer of Question 1 and would donate is the response to the answer of Question 2. The dependent variable equals the mean value of each choice. For example, choice $\mathrm{C}$ is corresponding to $\$ 115$. The independent variables 
$x_{i}$ represent the socio-economic characteristics, such as "family size," "child < 18-years-old," education level, race, gender, age, and income. The variable of "awareness of tree service" is defined as the total number of forestry agencies he/she knows, including the USDA Forest Service, the National Arbor Day Foundation, the International Society of Arboriculture, the Alabama Cooperative Extension System, the Alabama Forestry Commission, and the Auburn University School of Forestry and Wildlife Sciences.

For specific preferences, such as choosing the presence of trees at their home and communities, as well as special financial channels to support urban forestry, the ordered logistic model is applied instead of ordinary linear regression. Following the work of Zavoina and McElvey (1975), as discussed by Greene (1993), the ordered logistic model is set up in the following manner:

[3] $\quad y^{j}=\beta^{\prime} x+\varepsilon$

where $y^{j}$ is the level of choice to measure the preference to the dependent variables: "Having tree on property" $\left(\mathrm{y}^{1}\right)$, "Having tree in community" $\left(\mathrm{y}^{2}\right)$, and the support for "Alcohol \& tobacco tax" $\left(\mathrm{y}^{3}\right)$, respectively. The dependent variables are of three choices: low level of importance (scale $=6$ or 7); median level of importance $($ scale $=3$ to 5 ); high level of importance (scale $=1$ or 2 ). The value $\mathrm{x}$ is a vector of explanatory variables, $\beta$ an unknown parameter vector, and $\varepsilon$ is the error term. $\varepsilon$ is assumed to have a standard logistic distribution with mean 0 and variance $\pi^{2 / 3}$.

The marginal effects are nonlinear functions of the parameter estimates and levels of the explanatory variables. Hence, they generally cannot be inferred directly from parameter estimates. Marginal effects for distributions can be derived as follows:

[4]

$$
\begin{aligned}
& \frac{\partial\left[p\left(y_{i}=0\right)\right]}{\partial\left(x_{j i}\right)}=-\lambda\left(u_{1}-x_{i}^{\prime} \beta\right) \beta_{j} \\
& \frac{\partial\left[p\left(y_{i}=1\right)\right]}{\partial\left(x_{j i}\right)}=-\left[\lambda\left(u_{2}-x_{i}^{\prime} \beta\right)-\lambda\left(u_{1}-x_{i}^{\prime} \beta\right)\right] \beta_{j} \\
& \frac{\partial\left[p\left(y_{i}=J\right)\right]}{\partial\left(x_{j i}\right)}=-\lambda\left(u_{J}-x_{i}^{\prime} \beta\right) \beta_{j}
\end{aligned}
$$

Based on the equation (4), researchers can see one variable's marginal effect is related not only to its own coefficient, but also to the values of all other coefficients. Moreover, each observation and each level carry a distinct set of marginal effect values. In practice, marginal effects are generally calculated using the parameter final point estimates and average variable values. In this study, the marginal effects are calculated separately for every observation at three levels, respectively. The results are then averaged to provide a single, average response estimate for every variable, recognizing cumulative effects across the region. Results obtained in this way anticipate more global changes for the population of points and respect the multivariate distribution of parameter values (Wang and Kockelman 2009).

\section{RESULTS}

Table 1 lists the descriptive statistics of the study's data. Half of the respondents are employed full-time and one-third of them are re-
Table 1. Statistical summary of the participants.

\begin{tabular}{lc}
\hline Variables & Mean (std. dev) \\
\hline Should donate money & $48(50)$ \\
Would donate money & $34(36)$ \\
Annual income (in USD \$1,000) & $66(33)$ \\
Age & $51(13)$ \\
Family size & $2(1)$ \\
\# of children < 18 years old & $0.49(0.93)$ \\
& Frequency (\%) N=476 \\
\hline Employee status & 60 \\
$\quad$ Employed & 39 \\
$\quad$ Retired and unemployed & \\
Education level & 13 \\
$\quad$ high school & 25 \\
$\quad$ Some college & 61 \\
Bachelor's or higher & \\
$\quad$ African-American or others & 14 \\
$\quad$ White/Caucasian & 85 \\
Male & 60 \\
\hline
\end{tabular}

tired. The education level is relatively high: $61 \%$ with a bachelor's degree or higher. The respondents' average household income is USD $\$ 66,280$ which is relatively high compared to Alabama's average level of $\$ 42,000$ in 2007 . Approximately $85 \%$ of them are white and $13 \%$ are African-American; $60 \%$ of respondents are male.

The results indicate that people like trees in general (Table 2). "Improve the appearance of the community" and "Improvement in air quality" are considered the most important benefits of trees by the largest percentage of people. Attitudes toward the negative impacts are quite mixed: the potential cause for property damage is the most concerning factor. More importantly, the magnitude of the beneficial responses is never above 3 , yet all of the negative impacts are above 3 , suggesting the public's preference for the benefits of trees outweigh the negative sides or costs of maintaining trees.

The results indicate $80 \%-90 \%$ of respondents strongly agree that tree ordinances should be required on public property and new construction sites, but only $30 \%$ strongly agree that tree ordinances should be applied to individual-owned yards. Apparently, households prefer more flexibility to manage their own property.

In the survey, respondents were asked to indicate their attitudes toward "having trees on property" and "having trees in a community." The results show $85 \%$ of respondents who are looking for a residence such as a house or apartment indicate that having trees on the property is important, and more than $90 \%$ of respondents rate "having trees in the community" as important.

One interesting question to ask is whether this preference is associated with socio-economic and demographic characteristics of the individuals. The ordered logistic model is applied in the investigation. Ordered logistic regression assumes the coefficients that describe the relationship between the lowest versus all higher categories of the response variable are the same as those that describe the relationship between the next lowest category and all higher categories. This is called the proportional odds assumption (McCullagh 1980; Kim 2002). This assumption is rather strong and needs to be checked. The test result for the proportional odds assumption is not significant, suggesting that the assumption is satisfied and the ordered logistic regression is appropriate in this study.

The regression results and the corresponding marginal effects are provided in Table 3. The $\chi^{2}$ value of 15.22 and 15.94 sug- 
gests that both of the models are significant at a $1 \%$ level with 12 degrees of freedom. It is found that education level is positively associated with the tendency to prefer having trees on a property and within the community. For every one level increase in education (e.g., from high school to some college), a 0.63 increase in the expected log odds of moving to the next higher level of preference to having trees on a property was expected. When the respondent holds a college degree, the probability of choosing a high level of importance of having trees on their property is increased by $8.89 \%$. That is to say, people with a high level of educational attainment are more likely to consider having trees on their property as an important characteristic. Similarly, people with high levels of education also have tendencies to rate having trees within the community as an important characteristic.

Table 2. Ranking importance of urban forestry and management $(\mathrm{N}=470)$.

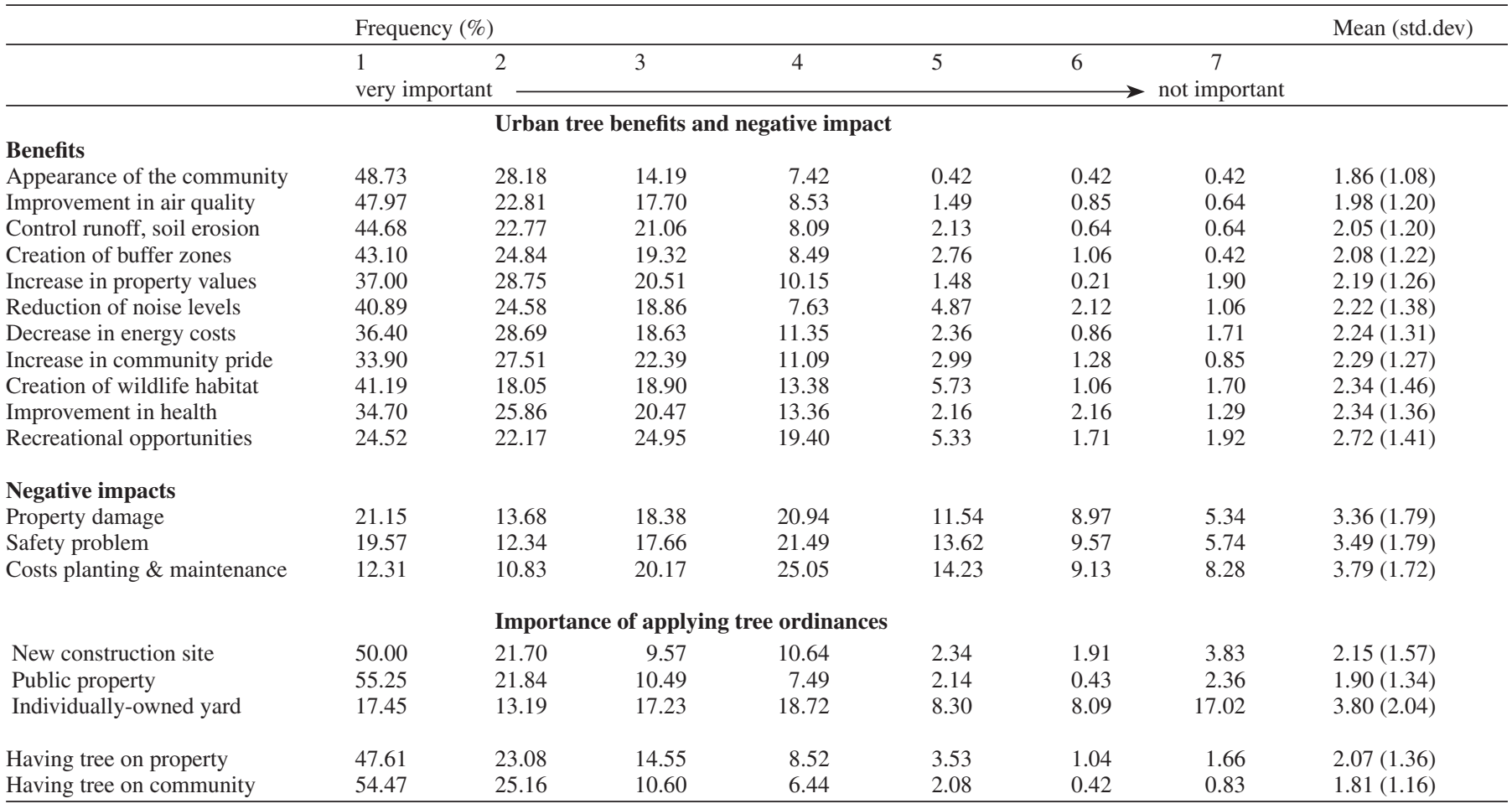

Table 3. Ordered logistic results and marginal effect for having tree on property and community. Funds in U.S. dollars.

\begin{tabular}{|c|c|c|c|c|c|c|c|c|}
\hline \multirow[t]{3}{*}{ Variables } & \multicolumn{4}{|c|}{ Have tree on property $\left(\mathrm{Y}^{1}\right)$} & \multicolumn{4}{|c|}{ Have trees in community $\left(\mathrm{Y}^{2}\right)$} \\
\hline & \multirow[t]{2}{*}{ Ordered logit } & \multicolumn{3}{|c|}{ Marginal effect $\%$} & \multirow[t]{2}{*}{ Ordered logit } & \multicolumn{3}{|c|}{ Marginal effect $\%$} \\
\hline & & $\mathrm{Y}^{1}=$ low & $\mathrm{Y}^{1}=$ median & $\mathrm{Y}^{1}=$ high & & $\mathrm{Y}^{2}=$ low & $\mathrm{Y}^{2}=$ median & $\mathrm{Y}^{2}=$ high \\
\hline Intercept 1 & $1.75^{\mathrm{z}}(0.13)$ & & & & $2.01^{\mathrm{z}}(0.15)$ & & & \\
\hline Intercept 2 & $-0.44(0.93)$ & & & & $-0.37(0.95)$ & & & \\
\hline Benefit of tree & $-0.001(0.01)$ & 0.03 & -0.01 & -0.02 & $-0.0004(0.011)$ & 0.01 & -0.006 & -0.004 \\
\hline Negative impact & $-0.04(0.03)$ & 1.01 & -0.42 & -0.58 & $-0.07^{\mathrm{z}}(0.03)$ & 1.78 & -1.03 & -0.74 \\
\hline $\begin{array}{l}\text { Awareness of } \\
\text { tree service }\end{array}$ & $0.004(0.07)$ & -0.10 & 0.04 & 0.06 & $-0.03(0.07)$ & 0.63 & -0.37 & -0.27 \\
\hline Family size & $0.21(0.16)$ & -5.07 & 2.14 & 2.93 & $0.25(0.16)$ & -6.06 & 3.51 & 2.54 \\
\hline Child $<18$ yrs & $-0.15(0.20)$ & 3.72 & -1.57 & -2.15 & $-0.20(0.21)$ & 4.72 & -2.74 & -1.98 \\
\hline College & $0.63^{\text {y }}(0.33)$ & -15.39 & 6.49 & 8.89 & $0.70^{z}(0.34)$ & -17.00 & 9.86 & 7.13 \\
\hline Bachelor & $0.16(0.31)$ & -3.78 & 1.57 & 2.18 & $0.27(0.32)$ & -6.55 & 3.80 & 2.74 \\
\hline White & $0.34(0.29)$ & -8.26 & 3.49 & 4.77 & $0.43(0.29)$ & -10.27 & 5.96 & 4.31 \\
\hline Male & $-0.09(0.21)$ & 2.10 & -0.89 & -1.22 & $-0.21(0.21)$ & 5.15 & -2.99 & -2.16 \\
\hline Age & $-0.003(0.008)$ & -0.08 & 0.03 & -0.04 & $0.002(0.008)$ & -0.05 & 0.03 & 0.02 \\
\hline $\begin{array}{l}\text { Income (in } \\
\text { thousand \$) }\end{array}$ & $0.001(0.003)$ & -0.03 & 0.01 & 0.02 & $0.001(0.003)$ & -0.04 & 0.02 & 0.02 \\
\hline Employed & $-0.41^{\text {y }}(0.23)$ & 9.92 & -4.18 & -5.73 & $-0.32(0.23)$ & 7.56 & -4.38 & -3.17 \\
\hline$\chi^{2}$ & 15.22 & & & & 15.94 & & & \\
\hline Likelihood ratio & 13.00 & & & & 14.46 & & & \\
\hline
\end{tabular}

${ }^{\mathrm{z}}$ statistically significant at $5 \%$ level

${ }^{y}$ statistically significant at $10 \%$ level

Note: "Awareness of trees service" is defined as the total number of forestry agency he/she knew at the time of the survey. Values in parenthesis indicate standard error. 
Table 4. The attitudes and preference for financing community trees programs.

\begin{tabular}{|c|c|c|c|c|c|c|c|c|}
\hline \multirow{3}{*}{ Variables } & \multicolumn{5}{|c|}{ Frequency $(\%)$} & \multirow{3}{*}{6} & \multirow{3}{*}{$\begin{array}{c}7 \\
\text { not important }\end{array}$} & \multirow[t]{3}{*}{ Mean (std. dev) } \\
\hline & 1 & 2 & 3 & 4 & 5 & & & \\
\hline & very important & & & & & & & \\
\hline State sales tax & 7.40 & 10.76 & 11.43 & 18.16 & 11.21 & 8.07 & 32.96 & $4.71(2.03)$ \\
\hline Local property tax & 14.32 & 14.54 & 14.99 & 15.88 & 8.50 & 7.38 & 24.38 & $4.09(2.14)$ \\
\hline Estate tax & 7.34 & 5.73 & 8.49 & 19.04 & 9.63 & 10.09 & 39.68 & $5.07(1.98)$ \\
\hline Alcohol and tobacco tax & 30.46 & 10.82 & 11.26 & 15.67 & 5.74 & 4.19 & 21.85 & $3.55(2.30)$ \\
\hline State income tax & 8.50 & 9.40 & 14.77 & 18.34 & 9.84 & 8.28 & 30.87 & $4.60(2.04)$ \\
\hline Corporate income tax & 23.45 & 12.83 & 14.82 & 15.49 & 5.53 & 6.19 & 21.68 & $3.72(2.23)$ \\
\hline Private donations & 42.64 & 22.86 & 13.85 & 11.87 & 2.86 & 1.10 & 4.84 & $2.32(1.61)$ \\
\hline Others & 38.37 & 10.47 & 6.98 & 9.30 & 2.33 & 3.49 & 29.07 & $3.35(2.57)$ \\
\hline
\end{tabular}

In contrast with retired respondents, employed individuals are less likely to consider having trees on their property, holding other variables constant. A one unit increase in the rating of negative impact of trees would reduce the probability to support having trees within the community by $0.74 \%$, suggesting that respondents who rate highly the negative impact of trees are less likely to support having trees in a community. However, most of the explanatory variables are not significant, such as income, family size, race, age, presence of young child, and gender, suggesting that people in general enjoy trees regardless of their personal characteristics.

Regarding the sources of public funding supporting a community's planting and maintenance of trees, the local government is considered by $60 \%$ of respondents to be important, while only $50 \%$ and $25 \%$ for state government and federal government, respectively. "Private donations" is also widely considered being an important source, but using taxes as a financial source is not largely supported with the exception of the "alcohol and tobacco tax" and corporate income tax. The "state sales tax," "local property tax," and "estate tax" each received low support (Table 4).

Since most people indicate that "private donations" is an important source for financing urban tree programs, their willingness to donate became an important question. In the survey, people were asked to rate their willingness to donate money and the willingness to volunteer time to support urban tree activities. Only $20 \%$ of the respondents indicated they are very likely to donate time or money toward a community tree program. This finding suggests that although people notice private donation is important for the establishment of community trees, they do not have a strong willingness to donate either time or money themselves.

Furthermore, when comparing the question of "How much should an average family support urban tree programs annually?" versus "How much would you like to donate annually?", it was found that, on average, donations for an urban tree program would be $\$ 14$ less than the money respondents think should be used to support such a program (Table 1). Without specifying the source of funding, most are inclined to say they like trees in residential areas and strongly support the urban forestry program. However, when respondents were asked to bear the costs either by all the community members or voluntarily, the amount of donation is more in question. To investigate what factors affect the amount of donations to urban trees programs, a multiple regression was conducted, and the results are presented in Table 5.

The results suggest that both models are significant at a $1 \%$ level. $\mathrm{R}^{2}$ in these two models indicate the variation is explained by the variables by $10 \%$ and $13 \%$, respectively. Factors that significantly influence the money respondents believe should be donated to support community trees are race, gender, and income. Factors significantly influencing a respondent's willingness to donate money (or would be donated) include gender, income, and the awareness of tree service. High income families will donate more for urban tree programs in both "should" and "would" models. However, the magnitude of money is 0.1 dollars higher for "would donate" than "should donate" for each one thousand dollar increase in annual household income. That is to say, an individual's donation decision is more sensitive to their income level. The public's knowledge of tree services significantly influences the amount of donation in the "would donate" model. A better knowledge of the forestry service agencies such as the USDA Forest Service will increase public support of an urban tree program.

Individual characteristics also matter in this case. White respondents, on average, believe that a family should donate $\$ 18$ more on tree programs than do African-American respondents. Males, on average believe a family should donate $\$ 14$ less than do female respondents. Family background such as family size, presence of child less than 18-years-old, working status, education lev$\mathrm{el}$, and age have no significant influence on the donation amount.

To explore the level of obtaining financing from the alcohol and tobacco tax, a logistic model is applied. The results of ordered logistic regression are presented in Table 6. The model is statistically significant at $1 \%$ level with a $\chi^{2}$ value of 31.04 . The results suggest that education level and being male are positively associated with the tendency to support alcohol and tobacco tax. For every one level increase in education (from high school to some college, from some college to bachelor's degree), a $0.5-0.7$ increase in the expected log odds were expect as one moves to the next higher level of support. The probability of having a high level of support increases by $13.44 \%$ and $10.36 \%$ for college education and bachelor's degree, respectively. That

Table 5. Regression results for donation willingness. Funds in U.S. dollars.

\begin{tabular}{lcc}
\hline Variables & $\begin{array}{c}\text { Should donate } \\
\text { (\$ per family) }\end{array}$ & $\begin{array}{c}\text { Would donate } \\
\text { (\$ per family) }\end{array}$ \\
\hline Intercept & $22.20(16.32)$ & $-19.71(12.04)$ \\
Awareness of tree service & $1.89(1.71)$ & $2.29^{\mathrm{z}}(1.19)$ \\
Family size & $0.55(3.82)$ & $-3.91(3.00)$ \\
Child < 18 yrs & $-4.74(4.99)$ & $-0.50(3.61)$ \\
College & $6.10(8.19)$ & $6.06(5.97)$ \\
Bachelor's degree & $9.42(7.86)$ & $-0.54(5.73)$ \\
White & $18.08^{\mathrm{z}}(6.78)$ & $2.07(4.96)$ \\
Male & $-14.01^{\mathrm{z}}(5.17)$ & $-6.58^{\mathrm{y}}(3.76)$ \\
Age & $0.07(0.21)$ & $-0.01(0.17)$ \\
Income (in thousand \$) & $0.17^{\mathrm{z}}(0.08)$ & $0.27^{\mathrm{z}}(0.06)$ \\
Employed & $-2.26(5.76)$ & $5.30(4.28)$ \\
$\mathrm{R}^{2}$ & 0.10 & 0.13 \\
$\mathrm{~F}^{2}$-value $\left(\chi^{2}\right)$ & 2.80 & 3.52 \\
\hline
\end{tabular}

${ }^{\mathrm{z}}$ statistically significant at $5 \%$ level

${ }^{\mathrm{y}}$ statistically significant at $10 \%$ level

Note:Values in parenthesis indicate standard error. 
Table 6. Ordered logistic results and marginal effect for alcohol \& tobacco tax. Funds in U.S. dollars.

\begin{tabular}{|c|c|c|c|c|}
\hline \multirow[t]{3}{*}{ Variables } & \multicolumn{4}{|c|}{ Alcohol \& tobacco tax $\left(\mathrm{Y}^{3}\right)$} \\
\hline & \multirow[t]{2}{*}{ Ordered logistic estimate } & \multicolumn{3}{|c|}{ Marginal effect $\%$} \\
\hline & & $\mathrm{Y}^{3}=$ low & $\mathrm{Y}^{3}=$ median & $\mathrm{Y}^{3}=$ high \\
\hline Intercept 1 & $0.99^{\mathrm{z}}(0.09)$ & & & \\
\hline Intercept 2 & $-1.31^{\mathrm{y}}(0.92)$ & & & \\
\hline Awareness of tree service & $-0.06(0.06)$ & 1.36 & -0.32 & -1.04 \\
\hline Family size & $0.05(0.16)$ & -1.13 & 0.27 & 0.86 \\
\hline Child $<18$ yrs & $-0.05(0.20)$ & 1.09 & -0.26 & -0.83 \\
\hline College & $0.73^{y}(0.34)$ & -17.61 & 4.16 & 13.44 \\
\hline Bachelor's degree & $0.56^{\mathrm{z}}(0.33)$ & -13.58 & 3.21 & 10.36 \\
\hline White & $0.18(0.28)$ & -4.45 & 1.05 & 3.40 \\
\hline Male & $0.29(0.21)$ & -7.02 & 1.66 & 5.36 \\
\hline Age & $0.01(0.008)$ & -0.26 & 0.06 & 0.20 \\
\hline Income (in thousand \$) & $0.002(0.003)$ & -0.05 & 0.01 & 0.04 \\
\hline Employed & $-0.002(0.23)$ & 0.06 & -0.01 & -0.04 \\
\hline$\chi^{2}$ & 31.04 & & & \\
\hline Likelihood Ratio & 14.92 & & & \\
\hline
\end{tabular}

${ }^{2}$ statistically significant at $5 \%$ level

${ }^{y}$ statistically significant at $10 \%$ level

Note:Values in parenthesis indicate standard error.

is to say, people with high education prefer the government to add tax to alcohol and tobacco users and the money can be a source of finance for community tree programs. Similarly, males are more inclined to support financing from alcohol and tobacco tax compared to females based on these findings. Other variables, such as race, age, income, working status, family size, and children, have no significant impact on support level probability.

\section{CONCLUSIONS AND DISCUSSIONS}

The findings from this study provide further support for the evidence found in previous studies that humans like trees (e.g., Clark et al. 2002; Lohr et al. 2004; Straka et al. 2005; Zhang et al 2007). People like to have trees on their property and in the community, an observation that is not based on their gender, age, race, income, and family background. The most favored amenity of trees is that trees improve the appearance of the community. Individuals with higher education have a higher tendency to have trees on their property. People with a high concern of the negative impacts of trees, such as the potential damage caused by trees, would be less likely to prefer trees in their community.

Further analysis on the characteristics contributing to an individual's willingness to donate money shed light on the study's policy implications, as people who have more information about urban tree programs and forestry services are more likely to donate money. Managers and planners should take more action to help public access to urban tree programs and encourage the public to participate in urban tree activities. Tree agencies also play a role in distributing information and providing technical support. To educate the public on the functions of urban tree programs is an important means of gaining their support, especially for small communities (Thompson and Ahern 2000). For example, providing public education and more accessible media information can increase public awareness of urban tree programs. Females and whites have a high tendency to donate money to a fundraiser. Higher family income would significantly lead to larger amount of donation. Therefore, a good economic environment helps in fundraising.

While evidence shows that there is significant demand for urban trees, financial support for urban trees does not match the growing demand. This is not surprising since demand would be high if the cost issue is not addressed. In contrast with many studies that primarily focused on the demand side or the attitudes toward urban trees, this study not only investigates public attitudes to trees but also the preferences to financing urban tree programs. While this study has its limitations in sampling size, response rate, and the questions formulated, the insights shed some light on current perceptions of financing urban trees programs, and provide some results for further investigation. The survey was targeted to citizens, a further investigation to mayors and city managers would be useful. Another limitation of the study was that the sample could be potentially biased due to the relatively low response rate. The sample population is from relatively high income, high education level families as compared to the average income and education levels in Alabama.

Acknowledgments. We gratefully acknowledge the financial support of the National Urban and Community Forestry Advisory Council Challenge Cost-Share Program (\#05-DG-11083150-160), and Urban \& Community Forestry Financial Assistance Program. We also thank the support provided by Ms. Yi Pan and Mr. Pengyu Zhu in the survey. The survey instrument was approved by the Auburn University Institutional Review Board. Comments from two anonymous reviewers are also greatly appreciated.

\section{LITERATURE CITED}

Arrow, K.J. 1951. Social choice and individual value. Yale University Press, New Haven.

Austin, M.E. 2002. Partnership opportunities in neighborhood tree planting initiatives: Building from local knowledge. Journal of Arboriculture 28:178-186.

Barro, S.C., P.H. Gobster, H.W. Schroeder, and S.M. Bartram. 1997. What makes a big tree special? Insight from the Chicagoland Treemendous Trees program. Journal of Arboriculture 23:239-249.

Bradley, G. 1995. Urban Forest Landscapes: Integrating Multidisciplinary Perspectives. Seattle: University of Washington Press.

Center for Urban Forest Research. 2003. Urban Forest Research Newsletter. Pacific Southwest Research Station, USDA Forest Service, Spring, 2003.

Clark, T.N., R. Lloyd, K. Wong, and P. Jain. 2002. Amenities drive urban growth. Journal of Urban Affairs 24(5):493-515.

Deng, J., K.G. Arano, C. Pierskalla, J. McNeel. 2010. Linking Urban Forests and Urban Tourism: A Case of Savannah, Georgia. Tourism Analysis 15(2):167-181.

Dwyer, J.E., D.J. Nowak, and G.W. Watson. 2002. Future directions for urban forestry research in the United States. Journal of Arboriculture 28:231-236.

Dwyer, J.F., E.G. McPherson, H.W. Schroeder, and R.A. Rowntree. 1992. Assessing the benefits and costs of the urban forest. Journal of Arboriculture 18(5):227-234.

Dwyer, M.C., and R.W. Miller. 1999. Using GIS to assess urban tree canopy benefits and surrounding greenspace distributions. Journal of Arboriculture 30(1):102-106.

Gorman, J. 2004. Residents' opinions on the value of street trees depending on tree allocation. Journal of Arboriculture 30(1):36-43. 
Greene, W.H. 1993. Econometric Analysis, 2nd Edition. Macmillan, New York.

Hauer, R.J., and G.R. Johnson. 2008. State urban and community forestry program funding, technical assistance, and financial assistance within the 50 United States. Arboriculture \& Urban Forestry 34:280-289.

Jim, C.Y., and W.Y. Chen. 2006. Recreation amenity use and contingent valuation of urban green spaces in Guangzhou, China. Landscape and Urban Planning 75:81-96.

Kelman, S. 1981. Cost-benefit analysis: an ethical critique. Regulation 5:74-82.

Kim, J. 2002. Assessing practical significance of the proportional odds assumption. Statistics \& Probability letters 65:233-239.

Lohr, V.I., C.H. Pearson-Mims, J. Tarnai, and D.A. Dillman. 2004. How urban resident rate and rank the benefits and problems associated with trees in cities. Journal of Arboricultural 30(1):28-35.

Lorenzo, A.B., C.A. Blanche, Y. Qi, and M.M. Guidry. 2000. Assessing residents' willingness to pay to preserve the community urban forest: A small-city case study. Journal of Arboriculture 26(6):319-324.

Majumdar, S., and Y. Zhang. 2009. Market for green signaling. The Business Review, Cambridge 13(2):87-92.

McCullagh, P. 1980. Regression models for ordinal data. Journal of the Royal Statistical Society Series B 42:109-142.

McPherson, E.G., J.R. Simpson, P.J. Peper, and Q. Xiao. 1999. Benefitcost analysis of modesto's municipal urban forest. Journal of Arboriculture 25(5):235-248.

Orland, B., J. Vining, and A. Ebreo. 1992. The effect of street trees on perceived values of residential property. Environment and Behavior 24(3):298-325.

Sagoff, M. 1988.The economy of the earth. Cambridge University Press, Cambridge, UK.

Saz-Salazar, S., and L. Garcia-Menendez. 2001. Willingness to pay for environmental improvements in a large city. Environmental and Resource Economics 20:103-112.

Sen, A. 1995. Environmental evaluation and social choice: contingent valuation and the market analogy. Japanese Economic Review 46:23-37.

Sommer, R., F. Learey, J. Summit, and M. Tirrell. 1994. The social benefits of resident involvement in tree planting. Journal of Arboriculture 20:170-175

Straka, T.J., A.P. Marsinko, and C.J. Childers. 2005. Individual characteristics affecting participation in urban and community forestry programs in South Carolina, U.S. Journal of Arboriculture 31:131-137.

Studer, N. 2003. Urban forest program development in Washington State municipalities. In: C. Kollin (Ed.). 2003 National Urban Forest Con- ference Proceedings, September 17-20, 2003, San Antonio, Texas. Washington, D.C.: American Forests, pp. 21-23.

Thompson, R., R. Hanna, J. Noel, and D. Piirto. 1999. Valuation of tree aesthetics on small urban-interface properties. Journal of Arboriculture 25(5):225-233.

Thompson, R.P., and J.J. Ahern. 2000. The state of urban and community forestry in California: status in 1997 and trends since 1988. California Department of Forestry and Fire Protection.

Tree Atlanta. Accessed May 1, 2010. <http://www.treesatlanta.org>

Tyrvainen, L. 2001. Economic valuation of urban forest benefits in Finland. Journal of Environmental Management 62:75-92.

Wang, X., and K.M. Kockelman. 2009. Application of the dynamic spatial ordered probit model: Patterns of land development change in Austin, Texas. Papers in Regional Science 88:345-365.

Wray, P.H., and D.R. Prestemon. 1983. Assessment of street trees in Iowa's communities. Iowa State Journal of Research 58:261-268.

Yen, S.T., P.C. Boxall, and W.L. Adamowicz. 1997. An econometric analysis of donations for environmental conservation in Canada. Journal of Agricultural and Resource Economics 22(2):246-263.

Zavoina, R., and W. McElvey. 1975. A statistical model for the analysis of ordinal level dependent variables. Journal of Mathematical Sociology pp. 103-120.

Zhang, Y., A. Hussain, J. Deng, and N. Letson. 2007. Public attitudes toward urban trees and supporting urban tree programs. Environment and Behavior 39:797-814.

Zhang, Y., B. Zheng, B. Allen, N. Letson, J. Sibley. 2009. Tree ordinances as public policy and participation tools: Development in Alabama. Arboriculture \& Urban Forestry 35(3):166-172.

Zheng, B., Y. Zhang, J. Chen. 2011. Preferences to home landscape: wildness vs. neatness. Landscape and Urban Planning 99:1-8.

Yaoqi Zhang (correspondence author)

School of Forestry and Wildlife Sciences

Auburn University

Auburn, AL 36849, U.S.

Zhangy3@auburn.edu

Bin Zheng

School of Forestry and Wildlife Sciences

Auburn University

Auburn, AL 36849, U.S. 
Résumé. Au moyen d'un sondage mené en Alabama aux États-Unis, cette étude fait une enquête à propos des opinions des résidants en milieu urbanisé par rapport aux arbres urbains et comment ils souhaiteraient contribuer aux programmes d'arbres en milieu urbain. Un modèle de classification logistique et une analyse de régression ont été utilisés pour les fins d'analyse. On a découvert qu'en général les gens préfèrent avoir des arbres sur leur propriété et au sein de leur communauté, et ce peu importe leur sexe, leur groupe d'âge, leur race, leur revenu familial ou toute autre caractéristique sociologique, mais les gens avec un niveau d'éducation plus élevé avaient tendance à apprécier encore plus les arbres. La contribution la plus appréciée des arbres est l'embellissement accru. Le risque potentiel de bris ou de blessure aurait pour effet de décourager les gens d'avoir des arbres au sien de leur communauté. On a découvert que le montant que chaque personne serait prête à donner volontairement est significativement plus faible que le montant que il ou elle estimerait que chaque personne devrait volontairement contribuer - par exemple via la taxation - pour supporter les programmes. La connaissance à propos de l'existence d'une agence et d'un service des arbres peut significativement accroître le montant que les gens sont prêts à consentir à cet effet. Alors que les dons privés sont largement acceptés en tant que source importante de financement, l'utilisation des taxes sur le tabac ou l'alcool comme source de revenu pour financer les programmes d'arbres urbains reçoit plus d'appui que l'idée d'une taxe corporative sur le revenu ou une taxe municipale. Les résultats indiquent que l'intérêt des citoyens à appuyer la foresterie urbaine varie en fonction de divers facteurs, ce qui fait qu'une approche holistique doit être retenue pour promouvoir les programmes d'arbres en milieu urbain

Zusammenfassung. Unter der Verwendung einer in Alabama, USA, durchgeführten Umfrage, untersucht diese Studie die Einstellung urbaner Anwohner bezüglich Stadtbäumen und ob sie es mögen würden, urbane Pflanzprogramme zu unterstützen. Ein bezogenes Logistik-Model und eine gewöhnliche Methode des kleinsten Quadrats wurden in die Analyse einbezogen. Es wurde festgestellt, dass im Allgemeinen die Leute bevorzugen, Bäume auf ihrem Grundstück und in der Gemeinde zu haben. Dies galt für alle Geschlechter, Alter, Rassen, Einkommen und andere Familienhintergründe, aber Individuen mit höherer Bildung hatten die Tendenz, mehr Bäume zu mögen. Der meist gewünschte Vorteil von Bäu- men ist die verbesserte Erscheinung. Die potentiellen Risiken und möglichen Unfallquellen würden sie entmutigen, Bäume in ihrer Kommune zu haben. Es wurde ferner festgestellt, dass die freiwillige Spende der Individuen deutlich geringer ist als die Menge, die er oder sie fühlt, wie jeder sie beeitragen sollte um die Programme (z. B. Bewertung) zu unterstützen. Das Bewußtsein für die Präsenz einer Baumagentur und Service die Höhe der freiwilligen Unterstützung deutlich erhöhen. Während private Spenden weitläufig als eine wichtige Quelle zur Unterstützung erachtet werden, erhielt die Idee, Steuereinkünfte aus Tabak- oder Alkoholverkauf zur Finanzierung von Pflanzprogrammen mehr Zuspruch als die Idee, Steuereinnahmen aus Gewerbebetrieb oder Grundstücksbesitz zu verwenden. Die Ergebnisse zeigen, dass die bürgerliche Bereitschaft zur Unterstützung von urbaner Forstwirtschaft von verschiedenen Faktoren beeinflusst wird. Daher ist ein ganzheitlicher Ansatz für die Promotion von Stadtbaumprogrammen erforderlich.

Resumen. Con base en una encuesta de Alabama U.S., este estudio investiga las actitudes de los residentes urbanos hacia los árboles y cómo harían para ayudar a soportar los programas. Se aplicó un modelo logístico y una regresión para el análisis. Se encontró, en general, que la gente prefiere tener árboles en su propiedad y en su comunidad para todos los géneros, edades, razas, ingresos, y otras historias familiares, pero los individuos con alto nivel educativo tienen una tendencia a gustarle más los árboles. Las ventajas más deseables de los árboles es la mejora de su apariencia e imagen. Los riesgos y peligros potenciales podrían desanimarlos a tenerlos en sus comunidades. Se encontró que cada persona voluntaria que está dispuesta a donar es significativamente menor que la cantidad que él o ella siente debería contribuir a soportar los programas (tasación). La conciencia de la presencia de una agencia del árbol y servicio puede incrementar significativamente la cantidad de donación que una persona está dispuesta a hacer. Mientras que la donación privada está ampliamente de acuerdo en la importancia, como fuente de apoyo, usando impuestos de alcohol y tabaco para financiar los programas de árboles urbanos que reciben ayuda con la idea de incorporarlos en los impuestos. Los resultados indican que los ciudadanos proclives a ayudar en los programas forestales urbanos están afectados por varios factores, por lo que se requiere una aproximación holística para promover los programas de árboles urbanos. 